\title{
Social Impact Bonds: The Next Phase of Third Sector Marketization?
}

\author{
Meghan Joy \& John Shields \\ Ryerson University
}

\begin{abstract}
The politics of austerity have pushed the third sector to the centre of attention as governments turn to nongovernmental institutions to pick up the social deficits created by economic recession. Some governments have begun supporting alternative service funding through such innovations as social impact bonds (SIBs), a financial product used to encourage the upfront investment of project-oriented service delivery. This article provides an understanding of what SIBs are and traces their emergence within Canada while linking them to their cross-national origins. SIBs are situated conceptually within broader contemporary developments within the nonprofit sector, particularly the agenda of public sector reform and third sector marketization. This analysis focuses on the potential impact of SIBs on nonprofit policy voice and their capacity to represent and meet diverse community needs.
\end{abstract}

\section{RÉSUMÉ}

Les politiques d'austérité ont accordé une place centrale au troisième secteur. En effet, les gouvernements dépendent de plus en plus des organisations non gouvernementales pour combler les déficits sociaux créés par la récession économique. Certains gouvernements ont commencé à financer des services au moyen d'innovations alternatives comme les obligations à impact social (OIS). Ces dernières sont un produit financier utilisé pour encourager l'investissement dans l'offre de services par projets. Cet article explique ce que sont les OIS et retrace leur émergence au Canada tout en soulignant leurs origines transnationales. Conceptuellement, on peut les situer dans le contexte de développements contemporains relatifs au secteur sans but lucratif, particulièrement la réforme du secteur public et la marchandisation du troisième secteur. Cette analyse se focalise sur l'impact potentiel des OIS sur la communication de politiques sans but lucratif et sur l'aptitude des OIS à représenter et rencontrer divers besoins communautaires.

Keywords / Mots clés : Nonprofit organizations; Third sector; Social impact bonds; Social innovation; Policy voice / Organisation à but non lucratif; Troisième secteur; Obligations à impact social; Innovation sociale; Communication de politiques 


\section{Joy \& Shields (2013)}

\section{INTRODUCTION}

The politics of austerity that arose in the wake of the 2007-2008 economic crisis in the West (Evans \& Fanelli, 2013; McBride \& Whiteside, 2011) has produced deep cuts to social services, just as the need for such support has been magnified. This situation has pushed the third sector to the centre of attention, most notably profiled in the Big Society initiative in the U.K. (Hilton \& McKay, 2011; Ishkanian \& Szreter, 2012)1, as governments turn to non-governmental institutions to pick up the social deficits created by economic recession and the state's retreat from social provision responsibilities.

The third sector, which includes a diversity of nonprofit organizations, has, at least since the reinventing government revolution of the 1990s (Osborne \& Gaebler, 1992), been seen as an important government partner lauded for its cheap, efficient, and innovative localized service delivery. Governments have been keen to support alternative service delivery as a way to shrink public sector costs and responsibilities (Evans, Richmond, \& Shields, 2005) and some have begun experimenting with tools to encourage alternative service funding through innovations such as social impact bonds (SIBs). SIBs are a financial product used to encourage private, philanthropic and/or public investors to provide upfront capital to support project-oriented service delivery by public, private, or nonprofit actors, or a combination of these actors.

The objective of this article is to provide an understanding of what SIBs are and why they have arisen at this conjuncture. Further, we conceptually situate SIBs within broader contemporary developments within the nonprofit sector, and trace the emergence of SIBs within Canada while linking them to their cross-national origins. Since SIBs are such recent creations, this paper limits its focus to a conceptual framing of this new policy tool and a critical discussion of the interest in its application in Canada.

The article begins by outlining how SIBs work-where the model originated and recent Canadian interest in its application. A conceptual frame is then developed that positions SIBs as a policy tool that represents a broader agenda of public sector reform and third sector marketization. Challenges associated with the development of SIBs for government, the third sector, and the private sector are discussed. Finally, an analysis that focuses on the potential impact of SIBs on nonprofit policy voice and their capacity to represent and meet diverse community needs is provided. It is argued that this voice function defines the third sector's ability to be innovative (Shields, 2013). This is an important and timely discussion given the power of SIBs to transform the third sector and recent Canadian interest in developing the tool further.

\section{SITUATING SIBS}

How do SIBs work and who is involved?

SIB development begins with a government entity engaging in a process of commissioning for service design and delivery. This involves the identification of a social service area and a distinct project deemed suitable for an SIB and the preparation of the bond by establishing the outcomes desired, the project costs, the anticipated future savings, and the rate of return to investors if project outcomes are met (Ainsworth, 2011). An intermediary organization, such as a foundation, partners with government to engage in this process of program design and to coordinate the delivery of the project. The intermediary issues the bond to one or several investors-who may be individuals, philanthropic foundations, insurance companies, banks and/or pension funds-who provide immediate project capital (Ainsworth, 2011). The intermediary subcontracts with one or several service providers from the nonprofit, public, or private sector who have proven innovative delivery approaches in the given service area. These service providers are paid up front to deliver a service that will maximize outcomes. An independent evaluator may be hired to ensure that project outcomes are 


\section{Joy \& Shields (2013)}

directly attributed to the SIB intervention. If the service project successfully achieves the outcome targets, the intermediary repays the bond to investors with the agreed upon rate of return (Loxley, 2013; Von Glahn \& Whistler, 2011).

In a binary SIB model, investors do not receive repayment if the outcomes are not met, while in a frequency scheme model, repayment depends on an increasing frequency of results (National Council for Voluntary Organizations, 2011). Because SIBs, particularly the binary variant, present considerable risk to investors and service providers, foundations or governments may be required to back up the original bond. In this scenario, investors will be repaid their original investment even if the project does not meet the outcome requirements, but they will not receive an additional rate of return.

\section{Where did SIBs originate?}

SIBs were developed in the U.K. as a component of public service reform. In 2011, the Open Public Services white paper committed government entities to commission with nonprofit and private service delivery organizations through payments by results, with SIBs being one way to facilitate payment (NCVO, 2011). The 2012 Caring for our Future white paper set out a plan to incorporate payment by results, and private and nonprofit service delivery into the reform of the adult social care market (National Development Team for Inclusion, n.d.). Central government facilitates this change by developing the supportive legislative framework, and local governments are tasked with developing the local care market (NDTI, n.d.). Central government has encouraged new social funding through Social Finance, a public company that invented the SIB concept and has facilitated the world's first SIB project; Big Society Capital, a social investment bank; and, a social stock exchange to be launched in late 2013 (Cabinet Office, 2013; Human Resources and Skills Development Canada, 2013).

There are currently 14 SIB projects in various stages of development in the U.K. The first and most closely followed is the Peterborough Prison project, which began in 2010. The Ministry of Justice commissioned the project with Social Finance, which raised capital from 17 individual and charitable investors and subcontracted four nonprofit organizations to work with 3,000 short-term male offenders to reduce recidivism over a six-year period (Social Finance, 2011). If the program is successful, meaning that the rate of reoffending is $7.5 \%$ below that of a comparator group, then the investors will receive a return ranging between $7.5 \%$ and $13 \%$, depending on the outcome per year over an eight-year period, a repayment consistent with a frequency scheme SIB (Social Finance, 2011).

The U.S. has also recently committed to SIB experimentation. President Obama devoted $\$ 100$ million to project development in the 2012 budget. The 2014 budget further illustrates this shift, with close to $\$ 500$ million in new funding dedicated to SIBs: $\$ 185$ million to extend the tool across government and $\$ 300$ million to create a Social Innovation Fund in the Federal Treasury Department (Loxley, 2013; HRSDC, 2013). To further enable SIBs, an Office of Social Innovation and Civic Participation was recently established to lead policy development and coordinate the Social Innovation Fund (HRSDC, 2013). Currently, there is a recidivism project underway in New York City that has received $\$ 10$ million in funding from Goldman Sachs, an investment backed by Mayor Michael Bloomberg's own private foundation through a loan guarantee offered to participating nonprofits (Chen, 2012). Further examples include two SIBs underway in Massachusetts in the areas of homelessness and youth recidivism, and a health impact bond trial in California aimed at asthma prevention for children through in-home intervention and monitoring (HRSDC, 2013; Clay, 2013). 


\section{Joy \& Shields (2013)}

\section{Canadian interest in SIBs}

In Canada, the federal government has shown the most significant interest in facilitating SIBs. Most recently, the Minister of Employment and Social Development, Jason Kenney, announced the federal government's intention to undertake two trial social finance programs in the areas of literacy and skills training (Curry, 2013). Though details have yet to be determined, the participating nonprofits, the Alberta Workforce Essential Skills Society and the Association of Canadian Community Colleges, will only receive federal funding support if they can improve test scores and attract private investment (Curry, 2013). Kenney's predecessor, Diane Finley, minister of the department formerly known as Human Resources and Skills Development Canada (HRSDC), had announced federal interest in exploring ways to enable communities to address localized social problems through partnerships with business (Government of Canada, 2012). In 2011, Finley established the Voluntary Advisory Council on Social Partnerships and in 2012 she launched an online policy engagement tool that solicited project and policy ideas for developing the so-called social finance market (HRSDC, 2013). Some 154 responses from diverse sectors described distinct "social innovation" projects that incorporated social enterprise, social investment funds, and SIBs (HRSDC, 2013). A follow-up report on the engagement tool outlines next steps for HRSDC in facilitating these forms of social innovation, including: 1) outreach via social media, seminars, and policy tables; 2) the development of policy tools to facilitate SIBs and payment by results, contracts, and investment funds; and 3) pilot projects in various domains of social innovation (HRSDC, 2013). The most recent budget, known as Economic Action Plan 2013, incorporates a section on social finance in which the government promises to facilitate a collaboration of nonprofit and private sector partners to develop "investment-worthy ideas" (Government of Canada, 2013). However, unlike in the U.K. and the U.S., this commitment lacks the formal identification of any allocation of program and fiscal resources at this stage.

Canada's provincial and territorial governments, which have the bulk of responsibility over the social policy domain, have shown interest in various forms of social innovation. Ontario, British Columbia, Alberta, Quebec, Nova Scotia, and Newfoundland and Labrador are all interested in or experimenting with social finance and payment by results schemes (HRSDC, 2013). In Ontario, particular reference was made to the use of SIBs in the Commission on the Reform of Ontario's Public Services report Public Services for Ontarians: A Path to Sustainability and Excellence, known more popularly as the Drummond Report. The report recommends the development of SIBs as a way to restrain government social service costs now and into the future in a context of economic uncertainty and increasing service demand (Commission on the Reform of Ontario's Public Services, 2012). To encourage SIBs, an Ontario Task Force on Social Finance recommended the development of a cross-sector working group to prepare design and delivery guidelines, needs assessment, and feasibility studies in different policy domains, and the creation of an intermediary organization-much like the U.K.'s Social Finance-to manage pilot projects (Ontario Task Force on Social Finance, 2011). However, the 2013 Ontario budget did not make mention of SIBs to fund social services. In its 2013 speech from the throne, Nova Scotia's NDP government made a loose promise that the province would be the first Canadian jurisdiction to implement a SIB (Lieutenant Governor of Nova Scotia, 2013).

Among third sector actors, the MaRS Discovery District has been the most vocal in its interest in supporting the development of SIBs in Canada. MaRS is a charitable organization that convenes public, private, and third sector partners to maximize entrepreneurial pursuits for economic, social, and environmental gain. In particular, its Centre for Impact Investing is actively involved in establishing SIB pilot projects, engaging in various outreach and learning opportunities, identifying and convening potential partners within the three sectors, and moving the agenda forward with policy advocacy (MaRS, 2012). 


\section{Joy \& Shields (2013)}

\section{CONTEXTUALIZING INTEREST IN SIBS}

The interest in SIBs as a policy tool cannot be divorced from a post-2008 economic recession context of government austerity, and the associated narrative of crisis in which society has to pay through spending cuts and individual and community self-reliance to ensure future economic and employment growth. The idea is that current and future economic uncertainty requires a plan to reduce social service costs and SIBs are seen by government as a key tool to achieve this end. In the context of austerity in the U.K., SIBs are framed as the "saviour of public services" and an alternative to all out service privatization because public dollars are used to maintain social service funding, albeit via the engagement of private sector and nonprofit actors (NCVO, 2011). SIBs enable current public dollars to be used to encourage other sectors to "invest" in social services to address "wicked policy problems." Central government encourages and supports local government SIBs that focus on place-based prevention with the idea that this will limit the use of more universal and institutional forms of care over the long term (Liebman, 2011; Von Glahn \& Whistler, 2011). This local and flexible program-based service design is intended to challenge a more top-down, expert driven, and siloed government approach to social policy design and delivery (Fox \& Alberton, 2011; Liebman, 2011; Loxley, 2013). Furthermore, government investment is supposedly more targeted and efficient because public dollars are only used to pay for results. Demands for greater transparency and accountability are to be met through consistent monitoring and outcome evaluation controls (Struthers, 2013).

SIBs present a way for government to transform the way it funds and delivers social policy, significantly transforming the third sector in the process. The SIB model is also designed to provide an immediate and relatively long-term payment for nonprofit organizations that participate to run specific programs with minimal delivery prescriptions. The promise of stable funding reduces the strain of constant fundraising, yearly funding uncertainty, and onerous reporting requirements (The Economist, 2012; Hayes, 2012; NCVO, 2011), and hence, provides a compelling incentive for nonprofit organizations to embrace SIB initiatives.

Nonprofits with a marketized service delivery model that are well networked, strongly resourced, and strategically located in a SIB bidding process, are favourably positioned to support the transition to SIBS. Foundations may also be supportive of the SIB tool as their policy and funding role is expected to grow. SIBs require a capable and well-funded philanthropic sector to act as intermediary organizations, to provide project capital, and to back up private sector investments. Foundations partner with government, private individual and corporate investors, and various nonprofit organizations, and thus have significant policy power in the SIB policy domain (Liebman, 2011).

There are many private sector motivations for supporting SIBs, some of which may be altruistic, but which also are driven by the desire to enhance competitiveness. There is also the added benefit of working to soften the image of corporations in an era where people have more access to information about exploitative practices in the domestic market and abroad. SIBS allow private investors to embellish their socially responsible image without having to sacrifice their drive to make profits, as is the case with charitable grants and donations (Chen, 2012).

SIBs may also be seen as part of the movement along the path of service privatization as they marketize demand and deliver services in some very lucrative areas such as hospitals, child care, and prisons (NCVO, 2011), which hitherto have had a dominant public sector presence. Furthermore, SIBs offer corporations greater access over government policy design and delivery decisions in service areas where they can make significant profit (Anner, 2010; Fooks, Gilmore, Smith, Collin, Holden, \& Lee, 2011). Market-oriented

ANSERJ To be notified about new ANSERJ articles, click subscribe / s'inscrire ici. 


\section{Joy \& Shields (2013)}

consulting firms, such as KPMG, see a promising business opportunity to work with private investors and government to conduct research and strategy on SIB projects.

Aside from a good business opportunity, SIBs are considered good public policy since they are said to be responsive to both taxpayer and service user interests. A KPMG report (2010) argues that the SIB model empowers consumers because projects are based on localized service needs. Moreover, the SIB targeting of wicked policy problems is seen as adding a new and powerful instrument to government's policy tool kit. It must be noted, however, that the advertised claims regarding SIB policy effectiveness are purely speculative as they predate the completion results from even the very first SIB cases in the U.K.

The political malleability of SIBs can also be seen as a strong selling point. For the political right, who have low trust in government and in the "special interest" charitable sector, the SIB focus on outcome accountability means that tax dollars only pay for actual results. Additionally, the use of market-based mechanisms to achieve a policy end lends itself favourably to conservative sentiments. While those politically to the left would reject narrow pay book democracy political formulas and be resistant to cuts to public investments in social policy funding, SIBs do hold a potential attraction. This rests in the promise of SIBs being about bottom-up citizen participation in policy design and evaluation, and preventative communityoriented care. However, those on the left would not see this as an exclusive alternative to well-funded institutional care provided as a right. Finally, citizens at the centre of the political spectrum would be drawn to the corporate social responsibility aspect of private sector involvement, particularly government encouraging large corporations to take on risk to "do good." The blending of state, business, and nonprofit actors under SIBs also holds appeal at the centre of the political spectrum.

\section{CONCEPTUALIZING SIBS}

\section{Social innovation}

SIBs are part of the recent public sector emphasis on reform through social innovation. HRSDC defines social innovation rather abstractly as "[p]roven ideas that work to address unmet needs by applying new learning and strategies to solve these problems" (HRSDC, 2013, p. 9). The Ontario Government's Innovation Agenda claims that innovation maximizes market value, facilitates market creation through the development of new firms and industries, and helps to solve social problems by linking ideas to markets (Ontario Ministry of Research and Innovation, n.d.). Social impact investing provides the capital needed to engage in innovative social projects and products, including SIBs (Canadian Task Force on Social Finance, 2011). Skills that facilitate innovation include business savvy, economic market analysis, and research capacity (Ontario Ministry of Research and Innovation, n.d.). This conceptualization of innovation is thus heavily marketized.

Social policy design and delivery through social innovation is framed against a big, hierarchical, and siloed government that has become disconnected from service users. The argument is that there has been a failure to produce adequate results through universal institutional care systems and grant-based funding to the nonprofit sector because investments are not linked directly to outcomes (Liebman, 2011). Traditional public sector and foundation grants distributed to nonprofits should thus be replaced by new policy instruments borrowed from the business sector (HRSDC, 2013). Struthers (2013) identifies traditional core public funding to nonprofits as "an old and untenable proposition" that risks becoming a future drain on public resources (p. 35). The role of government is to act as a catalyst for change and a facilitator of new partnerships through the development of new policy instruments such as SIBs (Ontario Ministry of Research and Innovation, n.d.; Struthers, 2013). Engaging in partnerships with the private sector and foundations allows government to leverage public dollars 


\section{Joy \& Shields (2013)}

to support nonprofit projects with proven results by either enhancing or widening the geographic distribution area and/or the service area of an existing project (HRSDC, 2013). The SIB model thus represents a new public-private partnership model for the nonprofit sector.

According to the Social Investment and Finance Team of the U.K.'s Cabinet Office, social finance will enhance the long-term sustainability of the nonprofit sector as it provides experience with social ventures that will build their market reputation and support further future investments (Cabinet Office, 2013). Nonprofits that have adapted over the last few decades to decreases in public and private funding as well as shifts away from core funding through entrepreneurial endeavours and collaborative partnerships are apparently leading the pack, ahead of more "entitled" organizations (Struthers, 2013). Social finance provides these marketized nonprofit organizations with the capital needed to advance their missions and expand their social projects (Ontario Government and Ontario Trillium Foundation, 2011). This represents a survival of the so-called financially fittest and most market-oriented nonprofits. In this new financing environment, many service-based nonprofits dependent on government contract financing may well fail because a marketized SIB model conflicts with their stated missions, values, and approaches, and they will not be well positioned to adapt to an even more marketized system of funding.

\section{New Public Management}

Social innovation and SIBs are part of a larger agenda to reform the public sector to operate more like a private business with many similarities to earlier versions of New Public Management. The familiar New Public Management language of value for money; free and enterprising bureaucrats; bottom-up reform; and empowering service customers (Evans, Richmond, \& Shields, 2005; Evans \& Shields, 1998) is prevalent in SIB framing. SIBs broaden the New Public Management language of alternative service delivery to include alternative service funding. The SIB model of lean and decentralized government is dichotomized against the welfare state form of top-down, universal, and institutionalized care in hospitals, jails, and shelters that deliver poor value for money (NDTI, n.d.; Preston, 2012). Service users are free to shape policy based on having choices in the area of provision (Institute for Government, 2010).

According to the National Council for Voluntary Organizations (2011), the payment-by-results mechanism of a SIB shifts the focus away from which sector is delivering the service and moves it in line with results. This reorientation could facilitate privatization as the difference between the three sectors becomes mute. Government no longer wastes time focusing solely on delivery, but zeroes its focus in on outcome, providing for a more efficient use of scarce public dollars (NCVO, 2011). SIBs represent a move away from government procurement of goods toward government commissioning for service delivery outcomes (Charities Aid Foundation, 2012). This is supposed to provide government with a more sophisticated understanding of local service markets and customers (Institute for Government, 2010). Through these reforms, government facilitates the development of welfare markets in which public, private, and nonprofit entities compete for service contracts (NDTI, n.d.).

A recent KPMG report (2010) on SIBs critiques New Public Management reform in the U.K. for its failure to link performance management to financial consequences through contractual procurement, and to truly free up service providers to advance social innovation. The report recommends a swift and comprehensive transition to the SIB model across all service areas (KPMG, 2010). A complementary "divestment" of bureaucrats to the private and nonprofit service sectors is also recommended (KPMG, 2010).

As with New Public Management, SIBs are to be used to transform nonprofit organizations into efficient and innovative market actors. Nonprofits are valued because they operate on scarcity principles, which are seen 
to inherently force innovation and are thus a valuable government partner in a model of alternative service delivery (Government of Ontario and Ontario Trillium Foundation, 2011; Struthers, 2013). There is a new focus on measuring the sector's "hard economic value," which challenges opinion that its work inhibits selfreliance and social innovation and is a waste of scarce public resources (Ontario Trillium Foundation, 2011). There remain questions as to whether SIBs will result in an increased concentration of nonprofit organizations through the merger of smaller organizations (NCVO, 2011).

The KPMG report (2010) on SIBs claims that the model supports the forging of new sectors that merge expertise rather than the layering and fragmentation endemic to earlier New Public Management reforms. Hayes (2012) is cautiously optimistic that forms of collaboration among smaller nonprofits could provide for more power in contractual negotiations with government and investors. Whether this translates to a stronger policy voice for the nonprofit sector and for citizens requires future study if SIBs become mainstream. Previous waves of third sector reform in Canada appear to have done little to enhance the voice of nonprofit actors (Shields, 2013).

\section{New Public Governance}

The SIB model has much in common with the New Public Governance approach, which has also been framed as a theory and a practical model that addresses the failures of New Public Management reform. Governance scholar Stephen Osborne (2010) claims that there has been a natural shift from a statist traditional public administration regime during the welfare state, to a short period of New Public Management and fragmented market-based service delivery, to a new steady state of pluralist policy implementation based on collaborative policy design, service delivery, and management.

In theory and practice, SIBs encourage blending the skills of multiple actors to design and deliver social services. The private sector has access to capital and knowledge of market discipline, the nonprofit sector has unique expertise in innovative service delivery approaches and familiarity with service clientele, and the public sector has the capacity to develop an overarching coordination framework (Webster, 2012). Coproduction with service users, family, and voluntary carers is also encouraged. According to Von Glahn and Whistler (2011), the SIB approach is not about privatizing public services but engaging in strategic partnerships that "scale up" local service delivery approaches with proven results. To facilitate SIB development, bureaucratic systems require more intensive collaborative service needs assessments to identify potential projects as well as service planning and design processes that address the fragmentation created through New Public Management reforms (Institute for Government, 2010).

SIBs depend on partnerships between many different nonprofit organizations, meaning that the model relies very heavily on the health of the sector and its ability to collaborate (Wolk, 2011). However, it is questionable whether SIB projects will run as smoothly as envisioned given the requirement of equal and trusting partnerships and the reality of competitive bidding processes (Webster, 2012). The power asymmetries between actors involved in collaborative service processes are rarely addressed by proponents of both New Public Governance and SIBs. Furthermore, Struthers (2013) admits that the relationship between government and nonprofit organizations is often turbulent, especially when nonprofits start to critique public policy more broadly or engage in more direct lobbying. The nonprofit sector is framed as an efficient service delivery agent rather than a meaningful policy voice that engages government in a democratic conversation about the diverse and intersecting needs of community and the values and norms that inform policy. In fact, the exercise of nonprofit voice in the neoliberal era has resulted in the stigmatization of these organizations as self-promoting special interests (Evans \& Shields, 2010; Shields, 2013). 


\section{CHALLENGES WITH SIB DESIGN AND IMPLEMENTATION}

\section{Challenges for government}

There is a consensus in the literature that the shift to SIBs will not reduce bureaucracy and cut public sector costs (Preston, 2012; NCVO, 2011; Fox and Albertson, 2011). The costs of administrative change required by a comprehensive shift to SIBs would be significant, requiring new skills for bureaucrats in market definition, program evaluation, and partnership building, and the associated information technology requirements (NCVO, 2011; Liebman, 2011). If a wholesale shift to SIBs results in significant public sector layoffs, the legal battles may be costly and the loss of stable and well-paid jobs will have wider negative economic consequences. Further, the idea that direct government funding, planning, and delivery of social programming is unable to be preventative-is inherently risk averse and cannot be tied to outcomes-is not founded on an evidentiary basis but rather on ideologically inspired conclusions (Loxley, 2013).

The SIB reliance on program evaluation presents a multitude of problems, particularly the lack of existing service approaches with proven financial track records as well as the uncertainty that a multitude of different approaches will deliver results in combination (Fiennes, 2013). Fox and Albertson (2011) recommend SIB pilot programs based on social experiments, but such studies are costly and time consuming, requiring additional investment that the private sector may be hesitant to take on. The issue of determining causation between an intervention and a result is also complex, and pilot projects should consequently choose all participants at random and include an identical control group to rule out other intervening variables. These are difficult conditions to meet in the real world of program design, implementation, and outcome evaluation (Fiennes, 2013). Even if positive results are achieved, it is difficult to attribute this to the SIB approach rather than a unique array of service interventions or an increase in money devoted to the service area (Fiennes, 2013).

Additionally, the so-called failure to achieve pre-defined results is not necessarily a problem if actual outcomes prevent the problem from getting worse, or if they contribute to improvements in social justice and opportunity over the long term (NCVO, 2011). Discontinuing funding to these equally preventative programs could result in serious welfare issues and associated costs in the future. Finally, the economic framing of SIBs tends to ignore the significance of politics on result figures. For instance, the number of young offenders may increase even with SIB programs if it takes place in conjunction with policies that support tougher prison sentencing, as in Canada (Fox \& Albertson, 2011).

The orientation toward outcomes may create an incentive for funders and delivery organizations to focus on those service types and groups most amenable to success, leaving the most marginalized users even more excluded (Loxley, 2013; NCVO, 2011). To prevent this, SIB payment schemes must ensure that the true cost of servicing the hardest to reach groups is met (NCVO, 2011). A strict results framework may also dissuade a nonprofit from responding to unique and unpredictable needs, placing into question the extent to which this approach is flexible and bottom up. Result frameworks should thus be designed through a partnership with all necessary government, nonprofit, academic, and service user actors (NCVO, 2011). However, the nonprofit sector in Canada has been actively dissuaded from embracing a more advocacy oriented policy voice and from informing government about service groups and social policy deficits. A leaner, more market-driven government risks losing valuable insight into the needs of citizens, particularly those whom are more vulnerable (NCVO, 2011).

\section{Challenges for the third sector}

Some nonprofit organizations are concerned that the move toward SIBs will reduce public, private, and philanthropic funding provided on a grant or donation basis (Preston, 2012). The tying of funding exclusively 


\section{Joy \& Shields (2013)}

to results is problematic for nonprofits because they do not have full control over outcomes and their "failure to produce" could threaten their continued existence if they incur the reputation of a "bad investment" (NCVO, 2011). The competitive bidding process that involves all three sectors places nonprofits at a competitive disadvantage compared to the public and private sectors, which have greater financial track records and more ready access to capital and resources to prepare a substantive bid (Hayes, 2012; NCVO, 2011). In addition, nonprofits are greatly restricted legally in terms of the amount of financial reserves they are allowed to carry forward each year and utilize for longer-term investments, let alone speculative ventures.

Small nonprofits in particular are much less likely to pay for financial and legal expertise to provide advice about SIB risk and contract negotiation (Charities Aid Foundation, 2012; NCVO, 2011). Furthermore, the shift to SIBs requires new management and evaluation skills for nonprofit staff, an investment that many nonprofit agencies, outside of the very largest, would struggle to afford. In the U.K., there have been instances of nonprofits being used by private sector actors as "bid candy" in which they are discarded after the contract is won through contractual re-negotiation (Webster, 2012). Though SIBs supposedly release nonprofits from heavy reporting requirements, they are likely to be just as burdensome in the demand for evaluation and monitoring of results (NCVO, 2011).

Much is made of the nonprofit sector as innovative and willing to take on risk for survival but this ignores the impact on job security for those employed in the sector (Webster, 2012). Small organizations in particular may need to work together to create umbrella organizations to support their participation in SIB projects and act as one voice before government (Hayes, 2012). Kirkpatrick (2011) cautiously envisions a future where small nonprofits shutter because of limited funding opportunities and larger nonprofits become even more marketized to compete against or work with private sector bidders for SIB contracts.

\section{Challenges for the private sector}

The private sector actually tends toward risk aversion, though the prominent SIB framing conveys the opposite, and will hesitate to invest money unless there is confidence that the investment will result in a substantive and secure financial return. Such investment practices are not conducive to the most innovative service delivery approaches (Economist, 2013; Liebman, 2011; Loxley, 2013). SIBs are a unique type of bond-like instrument that is particularly risky because all of the financial investment could be lost, the rate of return is capped, and investors are stuck with the product over the course of the project because SIBs cannot be turned into a liquid asset (Fox \& Albertson, 2011). This level of risk requires a proven record of financial viability and a scale large enough to make a healthy profit, neither of which is likely in the majority of SIB projects (Ainsworth, 2011).

Webster (2012) suspects that if a SIB funded program fails to deliver, private investors will use their power and influence to renegotiate the contract in order to get paid. The Economist (2012) magazine claims that SIBs are not all that different from the risky financial tools that precipitated the 2008 recession as they are similarly subject to overexposure, risk manufacturing, convolution that causes firms to profit from confusion, and a delay in government regulation and oversight. There is also the question of what occurs if a prime investor faces financial trouble over the duration of the project, with the most likely answer being to forsake the social impact investment and government having to foot the bill (Hanlon, 2011). This is more likely to occur during a period of economic slowdown when social need is at its highest. In a context where private investors are unwilling to fund large service projects and foundations do not have the cash to support such projects, government may need to make money available through the creation of new social investment funds, as has been the case in the U.K. and the U.S. (Loxley, 2013). This is a likely scenario in Canada given the relatively small philanthropic sector. 


\section{Joy \& Shields (2013)}

\section{DISCUSSION}

In addition to the more practical challenges associated with designing and implementing SIBs, there are deeper issues at the heart of the interest in the tool and the assumptions made by proponents that must be problematized. The financial recession, which frames the context and justification for SIB experimentation, had much to do with deregulation of the financial system and risky financial products, the failure of which society is paying for through severe austerity measures. The widespread implementation of and subsequent dependence on yet another risky financial tool with an unproven track record-SIBs-in an area as important as social care is a questionable policy option.

The support for philanthropy and private investment is supposed to speak to one's inherent altruism to give generously as individuals or as corporations to support good causes and the public interest. The model of philanthropy in the contemporary era was not intended to displace state-run social policy designed to at least modestly address inequality and to provide a protective layer for the most vulnerable as a right of citizenship. In fact, this foundation of state-provided social protection is necessary to support philanthropic efforts that help fill social gaps, address the needs of hard-to-serve populations, and partner with government to deliver publically supported programs (Evans et al, 2005; Salamon, 1995). Loxley (2013) is suspicious that interest in SIBs may be a way for corporations to privatize lucrative social services such as health care, childcare, prisons, and education. The SIB model may thus represent the next phase of marketization and privatization of social policy with the nonprofit sector being used as a legitimation strategy, or the aforementioned bid candy. This model utilizes an approach that uses the third sector rather than meaningfully partners with it.

SIBs are sold as a tool that enables society to effectively tackle complex policy problems through placebased prevention. Though the emphasis on prevention should be applauded, intractable societal problems risk being framed too narrowly as an individual's lack of self-responsibility (Kelly \& Caputo, 2011), as in the case of the Big Society initiative in the U.K. For instance, SIB projects have involved such activities as teaching incarcerated youth about empathy by having them write letters to the sick (Preston, 2012) and monitoring children with asthma to ensure that parents clean household mould (Clay, 2013).

Such a piecemeal strategy, which selectively targets the localized symptoms of complex socio-economic problems, risks ignoring the broader societal and economic reasons why the problems occurred in the first place, such as a lack of good stable employment and clean and safe affordable housing. Employment and affordable housing are examples of policy areas that tackle the roots of social problems, and they represent preventative efforts that government can do something about, challenging the SIB framing that government is inherently unable to deal with preventative policy. SIBs may represent a form of charity that happens to make money for private sector investors rather than a more holistic preventative social program. The kind of socialprofit organization created in the SIB model will be less willing to operate in an area where it cannot make money, which further limits the social justice and redistributive capacity of this project.

SIBs do speak to the need for public sector reform, particularly that policy should be tailored to and informed by localized needs in a way that challenges a top-down and siloed approach to policy design and delivery. However, SIBs may actually reduce the capacity for government to facilitate flexible policy because of the narrow framing of the nonprofit sector as a cheap and efficient service provider rather than a social and political actor that offers a representative voice to more deeply inform policy. Cheaper service provision is often the result of low pay and unstable working conditions for nonprofit staff, a precariousness that results in significant stress and staff turnover, limiting the sustainability of community connections (Shields, in press).

ANSERJ To be notified about new ANSERJ articles, click subscribe / s'inscrire ici. 


\section{CONCLUSION}

There is a need to expand, not reduce the vision of what the nonprofit sector does. The service role of the nonprofit sector is not just about delivering tangible services, and with SIBs now revenue generation, but also about ensuring that the policies that guide service delivery are informed by the needs and desires of the community. In this way, nonprofits act as a representative voice that links citizens to government and improves policy design and delivery. This knowledge of the community and the grounded feedback it gets from the community through engagement and advocacy is at the heart of the nonprofit sector's innovative nature, which is made more difficult when the sector is forced to become more bureaucratic, professionalized, and concerned with purely market-centred bottom lines. This innovative nature is especially true of small, localized nonprofits, who are likely the most at risk in SIB schemes, reminding us of the important diversity of the sector that must be maintained and of the inequities within the sector that SIBs may exacerbate. SIBs can be both empowering and disempowering, freeing and controlling, and it is important to assess who wins and who loses with the broad implementation of this policy tool. In particular, small, specialized, grassroots, and critical policy oriented nonprofit organizations have experienced defunding in the past two decades, which effectively silences community voices.

If government truly wants to support the third sector, it should provide stable and long-term funding that also supports core administrative costs and community engagement and organizing, as this provides a sustaining foundation for the third sector and empowers nonprofits to be innovative. Performing to get results and constant narrow auditing may blind service partners to niche issues as they arise on the ground, actually reducing their ability to be innovative.

There is also the question of who is defining results-powerful actors within the public, private, and third sectors or the community-and whether this definition encourages transformative social change. Nonprofits and their constituencies should be heavily involved in coming up with comprehensive and appropriate measures for defining the results of their work. Government can support the development of nonprofit research capacity in this area, particularly through encouraging community/university partnerships that can assist in assembling qualitative and quantitative data sets. The nonprofit sector can also assist in improving the community outcomes of public and private sector work, for instance via developing community impact assessments of public policy and private investment decisions. This represents a true partnership that balances the social role of the public, private, and nonprofit sectors and focuses on both broad and specific social needs.

\section{ACKNOWLEDGEMENTS}

The authors would like to thank Ted Richmond, Rob Howarth, and ANSERJ Editor, Peter Elson, for their helpful comments on earlier versions of this article.

\section{NOTE}

1. The Big Society is a policy idea that was advanced by the Conservative Party in the U.K. as part of its 2010 election platform. The subsequent Conservative-Liberal Democrat coalition government adopted Big Society as a broad policy direction aimed at creating the conditions to "empower" communities, civil society organizations, philanthropy, and local government to take on greater responsibilities regarding social policies and thus relieve central government from some of these obligations. At this point, the scope of the Big Society legislative reach is largely limited to England, though the intent is to 


\section{Joy \& Shields (2013)}

influence the discourse in all of the U.K. and beyond. The term Big Society is very much a flexible concept that can take on many different meanings. The looseness of its use gives it special value as a political and rhetorical device (Ishkanian \& Szreter, 2012).

\section{REFERENCES / BIBLIOGRAPHIE}

Ainsworth, David. (2011, November 1). Analysis: Can Social Impact Bonds help to create a better society? Third Sector. URL: http://www.thirdsector.co.uk/news/Article/1101352/Analysis-social-impact-bonds-helpcreatea-better-society/ [June 18, 2013].

Anner, Mark. (2010). Corporate social responsibility and freedom of association rights: The precarious quest for legitimacy and control in global supply chains. Politics and Society, 40(4), 609-644.

Cabinet Office, Social Investment and Finance Team. (2013, May). Achieving social impact at scale: Case studies of seven pioneering co-mingling social investment funds. London, U.K.: Crown Copyright.

Canadian Task Force on Social Finance. (2011, December). Mobilizing private capital for public good: Measuring progress during year one. Toronto, ON: MaRS Discovery District.

Charities Aid Foundation. (2012, September). Funding good outcomes: Using social investment to support payment by results (Putting Practice into Policy discussion paper). London, U.K.: Charities Aid Foundation.

Chen, David W. (2012, August 12). Goldman to invest in city jail program, profiting if recidivism falls sharply. The New York Times, p. A14.

Clay, Rebecca Fairfax (2013). Health impact bonds: Will investors pay for intervention? Environmental Health Perspectives, 121(2), p. A45.

Commission on the Reform of Ontario's Public Services. (2012). Public services for Ontarians: A path to sustainability and excellence. Toronto, ON: Queen's Printer for Ontario.

Curry, Bill. (2013, October 3). Tories launch 'social financing' programs to boost literacy and job skills. The Globe and Mail. URL: http://www.theglobeandmail.com/news/politics/tories-launch-social-financingprograms/article14696232/ [October 26, 2013].

The Economist. (2013, February 23). Social-impact bonds: Commerce and conscience, a new way of financing public services gains momentum. URL: http://www.economist.com/news/finance-and-economics/ 21572231-new-way-financing-public-services-gains-momentum-commerce-and-conscience [May 17, 2013].

The Economist. (2012, February 25). Playing with fire. 402, p. 3.

Evans, Bryan \& Fanelli, Carlo (Eds). (2013). Great recession-proof? Shattering the myth of Canadian exceptionalism. Alternate Routes: A Journal of Critical Social Research, 24 (2013). 


\section{Joy \& Shields (2013)}

Evans, Mitchell B., \& Shields, John. (2010). The third sector and the provision of public good: Partnerships, contracting and the neo-liberal state. In Christopher Dunn (Ed), The handbook of Canadian public administration (2nd edition) (pp. 305-318). Toronto, ON: Oxford University Press.

Evans, Bryan, Richmond, Ted, \& Shields, John. (2005). Structuring neoliberal governance: The nonprofit sector, emerging new modes of control and the marketization of service delivery. Policy and Society, 24 (1), 73-97.

Fiennes, Caroline. (2013, April 3). What the first social impact bond won't tell us: Two views on evaluating the pilot SIB in Peterborough, UK. Stanford Social Innovation Review. URL: http://www.ssireview.org/blog/entry/ what_the_first_social_impact_bond_wont_tell_us [May 16, 2013].

Fooks, Gary J., Gilmore, Anna B., Smith, Katherine E. Collin, Jeff, Holden, Chris, \& Lee, Kelley. (2011). Corporate social responsibility and access to policy elites: An analysis of tobacco industry documents. PLoSMedicine, 8(8), 1-12.

Fox, Chris, \& Albertson, Kevin .(2011). Payment by results and Social Impact Bonds in the criminal justice sector: New challenges for the concept of evidence-based policy? Criminology and Criminal Justice, 11(5), $395-413$.

Government of Canada. (2013). Economic Action Plan 2013: Jobs, growth and long-term prosperity. Ottawa, ON: Department of Finance. URL: http://www.budget.gc.ca/2013/doc/plan/budget2013-eng.pdf [May 16, 2013].

Government of Canada. (2012, November 8). The Government of Canada is taking action to address local challenges. URL: http://www.actionplan.gc.ca/en/news/government-canada-taking-action-address-local [May 16, 2013].

Hanlon, Robert James. (2011). Engineering corporate social responsibility: Elite stakeholders, states and the resilience of neoliberalism. Contemporary Politics. 17(1), 71-87.

Hayes, Sarah. (2012, February 15). Social Impact Bonds and small organizations-solution or nemesis? The Guardian. URL: http://www.guardian.co.uk/voluntary-sector-network/2012/feb/15/social-impact-bonds-smallorganisations?newsfeed=true [May 16, 2013].

Hilton, Matthew, \& McKay, James (Eds). (2011). The ages of voluntarism: How we got to the Big Society. Oxford: Oxford University Press.

Human Resources and Skills Development Canada (HRSDC). (2013, May). Harnessing the power of social finance: Canadians respond to the national call for concepts for social finance. Ottawa, ON: Government of Canada. URL: http://www.hrsdc.gc.ca/eng/consultations/social_finance/report/index.shtml [June 18, 2013].

Ishkanian, Armine, \& Szreter, Simon. (2012). Introduction: What is big society? Contemporary social policy in a historical and comparative perspective. In A. Ishkanian \& S. Szreter (Eds)., The Big Society debate: A new agenda for social welfare? (pp. 1-24). Cheltenham, UK: Edward Elgar Publishing. 


\section{Joy \& Shields (2013)}

Kelly, Katharine, \& Caputo, Tullio. (2011). Community: A contemporary analysis of policies, programs, and practices. Toronto, ON: University of Toronto Press.

Kirkpatrick, Philip. (2011, December 21). Is payment by results compatible with the big society? Third Sector. URL: http://guest.thirdsector.co.uk/2011/12/21/is-payment-by-results-compatible-with-the-big-society/ [June 18, 2013].

Downey, Alan, Kirby, Paul, \& Sherlock, Neil. (2010, June). Payment for success-How to shift power from Whitehall to public service customers. KPMG LLP. URL: http://www.kpmg.com/UK/en /lssuesAndlnsights/ ArticlesPublications/Documents/PDF/Market\%20Sector/Public_Sector/Payment_For_Success_WEB.pdf [December 13, 2013].

Liebman, Jeffrey. (2011). Testing pay-for-success bonds. Public Manager, 40(3), 66-68.

Lieutenant Governor of Nova Scotia. (2013, March 26). Turning the corner to a better future. Throne Speech. URL: http://nslegislature.ca/index.php/proceedings/throne-speech/ [July 12, 2013].

Loxley, John. (2013, January). Social Impact Bonds. Canadian Centre for Policy Alternatives Review (Economic and Social Trends). URL: http://www.policyalternatives.ca/sites/default/files/uploads/publications/ Manitoba\%200ffice/2013/01/CCPA\%20Review\%20Social\%20Impact\%20Bonds.pdf [June 18, 2013].

MaRS. (2012). Case studies in social innovation: MaRS centre for impact investing. URL: http://www .marsdd.com/articles/case-studies-in-social-innovation-mars-centre-for-impact-investing/ [July 6, 2008].

McBride, Stephen, \& Whiteside, Heather. (2011). Private affluence, public austerity: Economic crisis and democratic malaise in Canada. Halifax, NS: Fernwood.

Moss, lan, Institute for Government. (2010). The state of commissioning: Preparing Whitehall for outcomesbased commissioning. URL: http://www.instituteforgovernment.org.uk/publications/state-commissioning [November, 2013].

National Council for Voluntary Organizations (NCVO). (2011, November). Payment by Results (Discussion Paper). London, U.K.: National Council for Voluntary Organizations.

National Development Team for Inclusion. (n.d.). Be bold: Developing the market for the small numbers of people who have very complex needs. Carrier, J. Bath, U.K.: National Development Team for Inclusion.

Ontario Government and Ontario Trillium Foundation. (2011). The Partnership Project: An Ontario Government strategy to create a stronger partnership with the nonprofit sector. Toronto, ON: Ontario Trillium Foundation.

Ontario Trillium Foundation. (2011). Measuring the economic impact of the not-for-profit sector. URL: http://www.otf.ca/en/knowledgeSharingCentre/economic_impact.asp [July 6, 2013].

Ontario Ministry of Research and Innovation. (n.d.). Ontario's innovation agenda: Seizing global opportunities. Toronto, ON: Government of Ontario. 


\section{Joy \& Shields (2013)}

Osborne, Stephen P. (2010). The (new) public governance: A suitable case for treatment. In S. Osborne (Ed). The new public governance? Emerging perspectives on the theory and practice of public governance (pp. 1-16). London, New York: Routledge.

Osborne, David, \& Gaebler, Ted. (1992). Reinventing government: How the entrepreneurial spirit is transforming the public sector. Reading, MA: Addison-Wesley.

Preston, Caroline. (2012, November 9). Getting back more than a warm feeling. The New York Times, p. F.1.

Richmond, Ted, \& Shields, John. (2004). NGO restructuring: Constraints and consequences. Canadian Review of Social Policy, 53(Spring/Summer), 53-67.

Salamon, Lester M. (1995). Partners in public service: Government-nonprofit relations in the modern welfare state. Baltimore: Johns Hopkins University Press.

Shields, John. (in press). Constructing and 'liberating' temporariness in the Canadian nonprofit sector: Neoliberalism and nonprofit service providers. In R. Latham, V. Preston and L. Vosko (Eds). Liberating temporariness? Migration, work and citizenship in an age of insecurity. Montreal, QC: McGill-Queen's University Press.

Shields, John. (2013, June). Nonprofit engagement with provincial policy officials: The case of Canadian immigrant settlement services. Paper presented at the 1st International Conference on Public Policy, Grenoble, France.

Shields, John, \& Evans, Mitchell B. (1998). Shrinking the state: Globalization and public administration "reform." Halifax, NS: Fernwood Publishing.

Social Finance. (2011, November). Reducing reoffending among short sentenced male offenders from Peterborough prison. London, U.K.: Social Finance.

Struthers, Marilyn. (2013, June). Fair exchange: Public funding for social impact through the nonprofit sector. Toronto, ON: Metcalf Foundation.

Von Glahn, Drew, \& Whistler, Caroline. (2011, June). Pay for success programs: An introduction. Policy and Practice, 19-22.

Webster, Russell. (2012). Everything you wanted to know about Payment by Results but were afraid to ask. URL: http://content.yudu.com/Library/A1vzv4/Everythingyouwantedt/resources/index.htm?referrerUrl=http\%3A\%2F\%2F free.yudu.com\%2Fitem\%2Fdetails\%2F490992\%2FEverything-you-wanted-to-know-aboutPayment-by-Results [May 16, 2013].

Wolk, Andrew. (2011, October 25). What Social Impact Bonds mean for nonprofits and performance measurement. Root Cause. URL: http://rootcause.org/blog/what-social-impact-bonds-mean-nonprofits-andperformance-measurement [May 17, 2013].

Young, Niki May. (2011, May). Outcomes are 'easily manipulated' in payment-by-results contracts. civilsociety.co.uk. URL: http://www.civilsociety.co.uk/finance/news/content/9162/outcomes_are_easily_

ANSERJ To be notified about new ANSERJ articles, click subscribe / s'inscrire ici. 
manipulated_in_payment-by-results_contracts [May 16, 2013].

\section{ABOUT THE AUTHORS / LES AUTEURS}

Meghan Joy is a PhD candidate in the Policy Studies Program at Ryerson University, 350 Victoria Street, Toronto, ON M5B 2K3. Email: meghan.joy@ryerson.ca.

John Shields is a Professor in the Department of Communications and Culture at the Yeates School of Graduate Studies at Ryerson University, 350 Victoria Street, Toronto, ON M5B 2K3. Email: jshields@ryerson.ca. 